\title{
Курбаналиев Г.А. \\ К вопросу о процессуальном статусе дознавателя в современном уголовном судопроизводстве
}

Ростовский филиал ФГБОУ ВО «Российский государственный университет правосудия»

doi: $10.18411 / \mathrm{j}-05-2021-178$

(Россия, Ростов-на-Дону)

Научный руководитель Цой Б.А.

\section{Аннотация}

В статье исследуются основные полномочия и обязанности дознавателя, которыми он наделен в соответствии с УПК РФ, а также проблемы, связанные с их реализацией в ходе уголовно-процессуальной деятельности. Определяется, что процессуальный статус дознавателя, представляющий собой совокупность его прав и обязанностей, установленных нормами УПК РФ и соответствующих выполняемой им процессуальной функции, а также роль и место, отведенные этому участнику уголовного процесса, не в полной мере закреплен в УПК РФ. Делается вывод о том, что в УПК РФ необходимо внести соответствующие изменения, с целью восполнения пробелов в процессуальном статусе дознавателя.

Ключевые слова: уголовный процесс, дознание, дознаватель, орган дознания, прокурор, процессуальный статус, полномочия, самостоятельность.

\section{Abstract}

The article examines the main powers and duties of an inquiry officer, which he is endowed with in accordance with the Code of Criminal Procedure of the Russian Federation, as well as the problems associated with their implementation in the course of criminal procedural activities. It is determined that the procedural status of an inquiry officer, which is a combination of his rights and obligations established by the norms of the Criminal Procedure Code of the Russian Federation and the corresponding procedural functions performed by him, as well as the role and place assigned to this participant in the criminal process, is not fully enshrined in the Criminal Procedure Code of the Russian Federation. It is concluded that it is necessary to make appropriate amendments to the RF Code of Criminal Procedure in order to fill the gaps in the procedural status of the inquiry officer.

Keywords: criminal procedure, inquiry, interrogator, body of inquiry, prosecutor, procedural status, powers, independence.

Слово «дознание» происходит от таких русских слов, как «дознать» или «дознаться», означающих «выяснить, разведать, найти что-то или в чем-то удостовериться» [2, с. 18]. Впервые институт дознания получил законодательную регламентацию в Уголовно-процессуальном кодексе РСФСР в 1922 г. в гл. 8 «О дознании». Однако, кодекс не содержал конкретной нормы, определяющей правовой статус дознавателя. Лишь в некоторых нормах упоминалось лицо, производящее дознание, но при этом отсутствовало понятие данного участника уголовного процесса.

С течением времени институт дознания претерпел существенные изменения и получил четкое закрепление в УПК РФ 2002 г., в том числе было дано законодательное определение дознавателя. Так, согласно п. 7 ст. 5 УПК РФ: «дознаватель - это должностное лицо органа дознания, правомочное либо уполномоченное начальником органа дознания осуществлять предварительное расследование в форме дознания, а также иные полномочия, предусмотренные настоящим Кодексом» [1].

Не смотря на подробную регламентацию института дознания, следует отметить, что действующий УПК РФ не уделяет должного внимания процессуальному статусу 
дознавателя как лицу, производящему дознание. При этом УПК РФ уже трижды уточнял нормативное определение дознавателя, каждый раз вводя новые признаки данного участника, расширяющие как круг субъектов, охватываемых этим понятием, так и объем их полномочий. В связи с недостаточностью разработанности процессуального статуса дознавателя, на сегодняшний день возникает ряд проблем по вопросам взаимодействия дознавателя, следователя и оперативно-розыскных подразделений.

Для решения обозначенной проблемы рассмотрим важнейшие полномочия и обязанности дознавателя, которыми он наделен в соответствии с УПК РФ, а также проблемы, связанные с их реализацией в ходе уголовно-процессуальной деятельности.

Дознаватель, как субъект стадии возбуждения уголовного дела, т.е. лицо, уполномоченное принимать решение о возбуждении/ об отказе в возбуждении уголовного дела, обязан принять, проверить сообщение о совершенном или готовящемся преступлении и в пределах компетенции, установленной УПК РФ, принять по нему решение не позднее 3 суток со дня получения сообщения. сказанное сообщение. Согласно ч. 1 ст. 144 УПК РФ «при проверке сообщения о преступлении дознаватель, вправе получать объяснения, образцы для сравнительного исследования, истребовать документы и предметы, изымать их в порядке, установленном УПК РФ, назначать судебную экспертизу, принимать участие в ее производстве и получать заключение эксперта в разумный срок, производить осмотр места происшествия, документов, предметов, трупов, освидетельствование, требовать производства документальных проверок, ревизий, исследований документов, предметов, трупов, привлекать к участию в этих действиях специалистов, давать органу дознания обязательное для исполнения письменное поручение о проведении оперативнорозыскных мероприятий» [1].

Поводом для возбуждения уголовного дела могут быть только те сообщения о преступлении, которые получены из установленных законом источников. Помимо этого, любое сообщение необходимо принять, зарегистрировать и проверить, даже если в последствии окажется, что в деянии не содержится признаков какого-либо состава преступления и в итоге будет принято решение об отказе в возбуждении уголовного дела. Но главная проблема - это процессуальные сроки. Так, проверка сообщения о преступлении осуществляется в ограниченный срок: 3 суток, который может быть продлен до 10, а в исключительных случаях, предусмотренных ч. 3 ст. 144, до 30, которых часто не хватает, т.к. у дознавателей в производстве может находиться несколько уголовных дел или материалов дел.

Дознаватель обладает правом самостоятельного проведения следственных и процессуальных действий, а также принятием процессуальных решений, кроме случаев, когда требуется согласие руководителя органа дознания, согласие прокурора или решение суда (п. 1 ч. 3 ст. 41 УПК РФ). Однако, на дознавателя возлагается также проведение неотложных следственных действий. Под неотложными следственными действиями понимаются «действия, осуществляемые органом дознания после возбуждения уголовного дела, по которому производство предварительного следствия обязательно, в целях обнаружения и фиксации следов преступления, а также доказательств, требующих незамедлительного закрепления, изъятия и исследования» [1]. Однако, лицо, производящее неотложные следственные действия, не является дознавателем в процессуальном смысле слова. Так, если орган дознания поручает комулибо произвести неотложные следственные действия, то на арене появляется новый субъект уголовного процесса - лицо, производящее неотложные следственные действия, что требует законодательного подтверждения.

Несмотря на наличие определенных полномочий в уголовном процессе, все же дознаватель является должностным лицом, процессуальная самостоятельность 
которого ограничена, т.к. УПК РФ предусматривает обязательные для дознавателя указания прокурора, а также руководителя органа дознания и начальника подразделения дознания. Дознаватель кончено вправе обжаловать такие указания либо прокурору, либо вышестоящему прокурору, однако это не приостанавливает их исполнения, за исключением случаев, предусмотренных ч. 5 ст. 226 и ч. 5 ст. 226.8 УПК РФ.

Далее, следует отметить, что при осуществлении иных полномочий, предусмотренных п. 7 ст. 5 УПК РФ, дознаватель не выполняет функций ОРД, что характерно для органов дознания. Дознаватель выполняет только процессуальную функцию, которая следует из содержания ч. 2 ст. 41 УПК РФ, запрещающей привлечение в качестве дознавателей лиц, проводивших или осуществляющих оперативно-розыскные мероприятия по данному уголовному делу.

Отнесение дознавателя к участникам уголовного процесса со стороны обвинения (что вытекает из содержания Раздела 2 УПК РФ), не означает, что его обязанностью является сбор и доказывание виновности лиц в совершении преступления. Исходя из назначения уголовного судопроизводства, дознаватель должен способствовать всестороннему, полному, объективному расследованию уголовного дела. Так, ст. 73 УПК РФ определяет обстоятельства, подлежащие доказыванию по каждому уголовному делу, независимо от формы предварительного расследования и подследственности уголовных дел.

Следует отметить, что УПК РФ не указывает конкретных процессуальных решений дознавателя, требующих согласия руководителя органа дознания, за исключением ч. 4 ст. 225 УПК РФ. Таким образом регулируется процессуальная самостоятельность дознавателя. Но, проанализировав части 1, 3, 4 ст. 40.1 и ст. 41 УПК РФ следует сделать вывод, что дознаватель осуществляет свою деятельность под непосредственным контролем руководителя органа дознания, начальника органа дознания и прокурора.

В данном случае сложно говорить о процессуальной самостоятельности дознавателя, поскольку она ограничена полномочиями руководителя органа дознания, начальника подразделения и прокурора, которые имеют право давать письменные поручения дознавателю, которые обязательны для дознавателя, и их обжалование не приостанавливает их исполнения.

Дознаватель, являясь наряду со следователем лицом, проводящим расследование уголовных дел, в отличие от последнего, является наименее защищенным от возможного неправомерного воздействия со стороны заинтересованных лиц. Включение дознавателя в список лиц, в отношении которых применяется особый порядок уголовного судопроизводства, абсолютно необходимо.

Таким образом, процессуальный статус дознавателя, представляющий собой совокупность его прав и обязанностей, установленных нормами УПК РФ и соответствующих выполняемой им процессуальной функции, а также роль и место, отведенные этому участнику уголовного процесса, не в полной мере закреплен в УПК РФ. В связи с чем видится необходимым внесение соответствующих изменений в уголовно-процессуальное законодательство, с целью восполнения пробелов в процессуальном статусе дознавателя.

$$
* * *
$$

1. Уголовно-процессуальный кодекс Российской Федерации от 18.12.2001 № 174-Ф3 (ред. от 24.02.2021) (с изм. и доп., вступ. в силу с 07.03.2021) // Собрание законодательства РФ. 24.12.2001. № 52 (ч. I). Ст. 4921.

2. Мамаев Г.М. О некоторых проблемах правового статуса дознавателя // Государственная служба и кадры. 2019. № 2. 